\title{
Path-and Place-dependence of entrepreneurial ventures at times of war and conflict
}

\author{
Cherry Cheung, London South Bank University
}

Caleb Kwong, University of Essex

\begin{abstract}
Studies have previously examined the path development of entrepreneurs within a penurious environment but what if their path encounters a conflict situation? Does it make the place even more resource-poor and subsequently squeeze out any remaining life from entrepreneurism? Utilising Isaksen's (2014) characterisation of path-dependence, we intend to examine how entrepreneurs negotiate their path through the 'double whammy' of penurious environment and conflict. Through an event-based approach examining the entrepreneurial paths of three wartime entrepreneurs, our study indicates that, whilst the immediate aftermath is chaos leading to limited path-extension and even path-exhaustion, once the initial fog is clear, entrepreneurial individuals find different ways to adapt, not only through path-extension, but also through path-renewal and path-creation. These opportunities are place-dependent, the recognition of which requires considerable local knowledge and resources acquired through experience and prior local investment as well as interdependent networks.
\end{abstract}

Keywords: entrepreneurship, path-dependence, business history, conflict

\section{Introduction}

With previous studies suggesting that the rules and nature of entrepreneurship do change from one context to another (Baumol, 1990), there is a growing recognition that entrepreneurial behaviours cannot be explained without a good understanding of the underlying contexts (Zahra, 2007; Welter, 2011). However, with the majority of studies focusing on the business or sectoral contexts, other contextual dimensions, such as spatiality and temporality, are being somewhat overlooked (Zahra et al., 2014). Our study addresses the above imbalance by examining entrepreneurial behaviours within a unique contextual combination of a resource-poor spatial environment under the temporal situation of conflict. As both contextual dimensions are thought to impede economic activities, would conflict further deprive resource availability of a particular place, resulting in a drastic reduction in 
entrepreneurial activity, with many more entrepreneurial individuals seeing their entrepreneurship path being exhausted?

Conflict is a major source of paucity, destroying economic activities and livelihoods, and creating poverty on an endemic scale (MacSweeney, 2008). Whilst penurious in the sense of 'peripheral', 'thin' regions (Isaksen, 2014; Brekke, 2015), under-resourced nonprofit, public sectors (Ju and Tang, 2010; Modell et al, 2007) or declined industries (Grabher, 1993; Hassink, 2005) have been previously explored, the literature remains largely silent on the emergence and persistence of entrepreneurs under extreme poverty or adversity (Seelos \& Mair, 2007) such as conflict. With over 125 violent conflicts recorded worldwide since the end of the Cold War, killing an estimated seven million people and affecting the livelihood of even more (International Alert, 2006), we argue that the empirical focus on a conflict context is contemporarily relevant and deserves specific attention. A conflict context differs in its unpredictability, restriction of mobility, and dynamism, albeit in a regressive sense. International development agencies intending to provide support in conflict zones are often being held back by the high risk and cost associated with traditional relief interventions (Oberschall, 2007; Abdelbour and Branzei, 2010). Entrepreneurship (re)engagement represents an alternative, market-led and bottom-up capacity-building approach by offering a safety net in the midst of the destructive dynamics in conflicts (Honig, 2001). However, engaging in entrepreneurship entails considerable risk (Bullough et al., 2015), and without support the entrepreneurial outcomes could be fragile (MacSweeney, 2008). Therefore, understanding the meagre resources that entrepreneurs could utilise to seize opportunities may prove crucial to their survival. Moreover, little is known of how the changes arise from a conflict situation, not only in the transition from peace to conflict, but also as the conflict progresses, affecting the development paths of entrepreneurship. Understanding the factors 
that would enable entrepreneurs to continuously adapt is crucial in preventing their entrepreneurial spark being extinguished by unpredictable turbulence and regressive change.

To explore the dynamic nature of conflict, we apply the notion of path-dependence, which refers to the longitudinal development of firms, industry sectors and regions as nonrandom, purposeful evolution governed largely by an endogenous and continuous reflection of its own history and previous activities undertaken (Garud and Karnoe, 2001; David, 2000). Our study draws in particular on the categories of path-dependence developed by Isaksen (2014), namely, path-extension, path-renewal, path-creation and path-exhaustion, to explain the development of entrepreneurial ventures within our unique context. Studies have previously explored path-dependence from a penurious perspective and found path-extension to be preferred over the more radical approaches of path-renewal and path-creation (Brekke, 2015; Isaksen, 2014). We are interested to find out whether this is the case and, furthermore, how it changes over the period of conflict.

The role of place, or the spatial context, in the path-dependence process within a penurious, conflict environment also deserves to be further explored. Studies in economic geography have found that a penurious context often confines the absorption of relevant competencies, information and knowledge to those that are relatively close to the entrepreneur in terms of its cognitive, social, institutional and contextual attributes (Cohen and Levinthal, 1990). Such spatial proximity allows an interdependent local entrepreneurship ecosystem to be developed, which can be crucial in enabling enterprising individuals to speedily evaluate the value and magnitude of both opportunities and risks (Short et al., 2010). In the context of conflict with high uncertainty and restricted physical mobility, whether place can act as a facilitator or hindrance remains unknown. 
We believe the well-established notions of path- and place-dependency respectively from management and economic geography offer us the longitudinal and spatial lens to examine how entrepreneurial resilience can be developed in uncertain environments, which is an emerging field within the entrepreneurship literature (Cope, 2011;Hayward et al., 2010; Bullough et al., 2015). To extend the current state of research, our study intends to find out how entrepreneurial individuals from a penurious environment might behave when this environment enters a period of conflict, and how place may affect the path-dependence process in such a context.

Our study contains two major research questions:

1. What are the characteristics of path-dependency of entrepreneurial ventures when a penurious environment enters the context of conflict?

2. What are the roles of place in influencing the path-dependent development of ventures in the context of conflict?

Whilst previous studies such as Isaksen (2014) and Brekke (2015) have examined the impact of place on path-dependence from the point of view of the macro-level regional innovation system, or as Ju and Tang (2010) did from a sectoral point of view, our study takes a different approach in examining at the micro-level how individual entrepreneurs navigate a penurious local environment. Although utilised micro-level analysis is not uncommon (Eriksson et al., 2000; Patel and Pavitt, 1997), few have done so in a penurious, conflict context. Moreover, few examine path- and place-dependence from the point of view of a low-technology context, with most studies focusing on high-tech, knowledge-based variants (Tushman and Anderson, 1986; Tushman and Romanelli, 1985).

In the sections that follow, we first examine the role of resources and place within the existing framework of path-dependence. We then turn our particular focus to the context of conflict. After reviewing the literature we discuss the context of the study and the cases, as 
well as the methodology adopted. We then reveal the findings of the paper before considering some of the key characteristics of path- and place-dependence for our specific context in the discussion and conclusion sections, where managerial and policy implications are also discussed.

\section{Path-dependence entrepreneurship development in a penurious environment}

The theory of path-dependency posits that the developmental path that an entrepreneur chooses is historically-determined (Guard and Karnoe, 2001; David, 2000). The heterogeneity of the entrepreneurship process highlighted in the entrepreneurship literature, most notably, effectuation (Sarasvathy, 2001), indicates that the different cognitive frameworks of entrepreneurs and the different factor endowments they can mobilise result in ventures developing from different starting points (Shane, 2000; Baron, 2006). As their entrepreneurship journeys unfold, emergent events, whether success or failure, will in turn generate newer skillsets and resources, resulting in expectations for the future flexibly defined and constructed (Gaurd et al., 2010). In distinguishing the different pursuance paths that rely on the resources and competencies previously accumulated, Isaksen's (2014) categorisation of path-exhaustion, path-extension, path-renewal and path-creation is particularly relevant to this study and is highlighted in Table 1.

Previous studies have found that ventures operating in a penurious environment tend to embark on path-continuing strategies (Isaksen, 2014; Brekke, 2015). Resource-constrained entrepreneurs deploy strategies such as reconfiguration to minimal resource usage (Nelson and Baker, 2005), reinforcing incremental rather than path-breaking changes as one may expect to find in a munificent context (Desa and Basu, 2013). The uniqueness of conflictinflicted paucity lies in the sudden systemic shock causing rapid deterioration of resource availabilities (MacSweeney, 2008). Such uncertainties could intensify risk-adverse 
behaviours (Miller, 1992), reinforcing path-continuation. Alternatively, necessity may push them towards path-breaking endeavours that deviate from their pre-existing competencies and prior specialisations (Coble, 2003). Our study intends to further explore how the two opposing forces play out in the minds and behaviours of entrepreneurial individuals facing conflict situations.

\section{Place-dependence entrepreneurship development in a penurious environment}

Place-dependency, a concept from economic geography that remains little-known in management and entrepreneurship disciplines, refers to the embeddedness of the entrepreneurial path-development within the place-specific technologies, competencies and resources (Brekke, 2014). Spatial proximity is seen as crucial in enabling entrepreneurs to develop networks that facilitate the sharing of infrastructures (Saxenian, 1994; Gulati, 1999), accessing place-specific physical and financial resources (Audretsch and Keilback, 2007; Becattini, 1990), and is conducive to learning, knowledge exchange and collaboration (Boschma, 2005). Over time, the emerging paths of the entrepreneurs are further reinforced by place-specific positive externalities and economies of scale (Sydow et al., 2009), resulting in them devoting further resources and competencies along certain spatial specialisation(s) (Vergne and Durand, 2010). This suggests that the path-development process is also placedependent, hence understanding that the particular context in which the entrepreneurs are embedded is crucial in understanding their entrepreneurial path.

Within a penurious context, studies have suggested that the path-development process is particularly locked-in to the locality as the weak endogenous dynamism caused by resource paucity results in the increased reliance on internal resources and personnel (Isaksen, 2014; Brekke, 2014). Over time, this weakens the absorptive capability of entrepreneurs, who become increasingly disconnected from the innovations of the wider national innovation 
system (Isaksen and Karlsen, 2012). In turn, this further confines them to a localised, DUI mode of incremental innovation, reinforcing path-continuing behaviours (Jensen et al., 2007). Path-breaking requires what Martin and Sunley (2006) termed as 'transplantation' - the monumental exogenous input into the local innovation system (Todtling and Trippl, 2005), which can be a large injection of external investment (Isaksen, 2014), top-down policy initiative (Brekke, 2014), or capacity development and support schemes connecting enterprising individuals to the global knowledge networks (Lagendijk and Lorentzen, 2007).

A conflict situation is likely to further reinforce place-dependence. Access to the wider innovation system will be limited with warfare, destruction of infrastructures and lack of physical mobility amongst affected individuals. Moreover, attributes required for transplantation are even harder to come by, with a frail government (Menkhaus, 2003), rapid deterioration of an educated and skilled workforce (Ender, 2010), and a halt on inward investments (Bussmann, 2010). This begs the question of whether path-breaking endeavours are practically feasible. Moreover, the nature of place-dependency, including the types of local resources and competencies that entrepreneurs under conflict context may be relying on, remains unclear from the existing literature.

\section{Research Context}

Our study documents the entrepreneurship journeys of three aspiring entrepreneurs who were approaching adulthood and first started a business during the period of the Japanese occupation of Hong Kong (profiles in Table 2). The entrepreneurs were brought up as nomadic haulers carrying goods between freighters anchored in the Victoria Harbour and the shore. In the early part of the $20^{\text {th }}$ century, Hong Kong was a stagnant, British colony with entrepôt trade with China being its main commercial activity (Endacott, 1958). The harbour had long been seen as a penurious part whereby jobs in haulage were characterised as being 
unskilled, poorly paid and involving hard labour and long working hours (Chan, 1980). Most of these jobs were usually taken by the local inhabitants, the fisherfolk, who lived a subsistence existence. Brother Fok recalled:

Seven of us lived on a two-metre-long sampan. We cooked aboard and slept leaning on each other ... we were barefoot, never had nice clothes, nor a spacious or comfortable place to live, but we only prayed to avoid typhoons, which could destroy our boat and the whole family (Leng, 2010, p6-7).

Most fisherfolk were born, married and died on their boats, with restricted interaction with landsmen as a result of centuries of stigmatisation, marginalisation and humiliation (Anderson, 1972; Ward 1985; Chan, 2000). Sister Yip reported an isolated, locally-confined existence:

As children we played with other sisters (fisherfolk girls) at the shallow end, sometimes along the creek under Gooseneck Bridge. We bought everything from the marketplace above the bridge (stretched along the harbour front). My favourite was Ma-Po-Shan, a biscuit store, a hat of crumbs for two cents! The sellers were landsmen, but we had few dealings beyond market exchange. We were easily recognised: barefoot, in fisherfolk costumes and speaking with an accent. Our relatives lived in boats around the harbour. We would row over or take the tram (running along the harbour front) for a visit... My father would visit land more often as he would conduct businesses from a tea house, as well as visiting opium, gambling and prostitute dens on shore... Sometimes offloading goods would take us to the other side of the harbour. There was also a boatyard for repair and maintenance.

Fear of discrimination played a part in their narrowed worldview. Sister Li recorded incidents of being discriminated against by teachers and classmates during her short time in school. Sister Yip recalled that people would occasionally shout abusive comments, or run away like they had seen a ghost. This is consistent with the description provided by Ward (1965), that fisherfolk were "dragons on water, worms on shore".

Nevertheless, decades of close interaction amongst a small and isolated group helped them to develop trust and repeated interaction, as well as routines, practices and terminologies. Both Sister Li and Sister Yip mentioned the emphasis on rules and orders, including, '... how new customers can be found, the types of goods allowed to carry, and even 
the coolies that were deemed employable.' The structure of the trade was largely senioritybased and favoured incumbents over new entries. Unsurprisingly, all three families had been involved in haulage for generations. Deviation from the expected norm would be illegitimised through peer pressure, boycotts and other informal means, and could result in the non-conformists suffering great losses both in profit and reputation (Kim and Markus, 1999).

This tacit, professional knowledge and other skills would take years to master. Fisherfolk aged five would begin to learn to steer a boat, watch the currents and weather changes and, by their adolescence, became involved in the physical side of the operation. Whilst the family head would continue to handle commercial development, the children would become increasingly involved in its day-to-day supervision and management, including the daily arrangement with the coolie heads of the appropriate manpower, managing accounts, and accompanying the family head to negotiations. By late teens they would be assisting the head to run a separate boat. Through such an informal 'apprenticeship' process, the young ones would have accumulated useful network, technical and market knowledge to run their own business once they had accumulated sufficient capital, often with family help. The first few years of running the business independently in such an institutionalised environment could be extremely tough. Those who struggled would eventually be pushed out of the business and became coolies, labourers, or beggars around the harbour, until they accumulated enough to restart. Once a foothold in the trade had been obtained, most would reinvest in more and larger fleets to attract bigger business. When approaching retirement, assets would be split amongst offspring, thus restarting the cycle.

All three entrepreneurs were reportedly going through the 'apprenticeship' process. Sister Yip recalled: 
I worked on my father's boat since I was little. My big mother who slept next to me would kick me up to make rice porridge, or to buy fried breadsticks from the market. Later, I would pull the boat into the harbour, and helped with liftings. At night I would, with a few sisters, wash beanie sacks and prepare them for the next day. I fed people and chickens on board - their mess needed to be cleaned up.

Sister Yip was perhaps more fortunate in having a senior figure as a father, unlike Sister Li whose family was in the transitional phase having been forced out of haulage and into inshore fishing and clam digging. Brother Fok experienced a more traumatic childhood. He lost his father through cancer and two elder brothers through a typhoon at seven and, with the loss of manpower, the family abandoned their haulage business. However, rather than use the residential sampan for small-time trade, his mother's decision to uproot the family ashore required considerable courage and risk-taking, and was unheard of at the time. Whilst the gamble did not pay off with the family eventually returning to haulage, the family remained ashore. Exposure to the perspectives of landsmen and noting some of the successes associated with education would have an important impact on Mother Fok who became insistent on her son's education. Brother Fok recalled:

My mother was illiterate but she understood the importance of education, to do well in life... I attended free schools for fisherfolk... then was admitted into Queen's College, a premier secondary... she would give me pocket money for the tram and for lunch, but I would walk and eat cheaply... To reduce the family burden, once I finished school, I helped with bookkeeping, distributed invoices, and distributed wages to those running sampans (Leng, 2010, p.9-11).

Fok's experience is in sharp contrast to the typical fisherfolk. Sister Yip recalled:

My brothers attended school sporadically and my father did not object when they quit altogether. Once I saw one of them playing games on the street and told my father, but he didn't want to know. They can write a little. I wanted to go but my father would say, "What's the point of girls going to school?".

Sister Li began her studies, but was recalled after 6 months to help make money. She nevertheless spoke of the importance of basic arithmetic and literacy in aiding her bookkeeping, stock checking and contract signings. Brother Fok's education not only enabled him to offer technical support to his mother's business, but also gave him a pro-land 
worldview and the competencies and networks well beyond what was required for surviving in the harbour. He is what Johnson (1993) described as the 'imaginative extension' of the stereotypes which the literature suggests are most dynamic and can potentially bring about changes through 'situated application' (Tsoukas and Chia 2002). The presence of both groups in our study helps give a clue as to whether these personal factors play a role in their path development process in conflict situations.

\section{Methodology}

\section{Data Collection}

Our study follows the biographical research method (Bornat, 2008; Merrill and West, 2009; Grele, 1996; Thompson, 2000), focusing largely on the establishment of facts surrounding the entrepreneurial decisions taken by the three entrepreneurs during the period of conflict (Portelli, 2006; Thompson, 2000). Our intention is to explore the entrepreneurial actions taken and how this is linked to pre-existing and newly acquired resources and competencies. Our chosen approach is particularly suitable for this research for a number of reasons. Firstly, limited access to respondents at the time of conflict means that to adopt a post-hoc, historical approach is pragmatically inevitable. Secondly, biographical research facilitates a humanistic-interpretive approach that often enables researchers to offer a fresh perspective that, in some cases, confirms, and in others, challenges, many of today's intermingled theories and assumptions that were developed from the normative model of the West (Jones and Zeitlin, 2008). In entrepreneurship, there is an increasing consensus on the importance of context to the understanding of the cognition of entrepreneurs and the entrepreneurial decisions being made over time (Jones and Wadhwani, 2006). More specifically, history shapes the actions of the characters at the particular time. Although biographical materials can be considered to be similar to other narratives, the uniqueness of them lies with their 
extensive coverage of life events (Thompson, 2000), which enables us not only to pinpoint the particular activities undertaken during the period concerned, but also to reconstruct how prior resources and competencies shaped their adaptation process and the evolution of their ventures (Rosenthal, 1993). Thirdly, the longitudinal emphasis of biographical research is most suitable for a change-orientated topic such as path-dependency (Merlin, 1992; Chetty et al., 2014). Finally, our emphasis on individual testimonies that detail the local, native and marginalised points of view is particularly important in a conflict situation where records were destroyed or rarely kept (Thompson, 2000; Portelli, 2006).

The extensive effort required to extract longitudinal details and the difficulties in finding suitable informants for the restricted context of conflict (Goodhand, 2000) means that we had to restrict the number of entrepreneurs studied to three, which is consistent with previous research using an in-depth qualitative approach (Jack et al., 2008). The interviews were extracted from different sources and consequently there are differences in terms of content and forms displayed (Table 3). Nevertheless, reusing secondary archival materials after careful deconstruction and recontextualisation is not uncommon in biographical research (Tureby, 2013), particularly when our focus is on the referential function of the narrative (i.e. the sequence and responses) rather than feelings and emotion.

\section{Data Analysis}

Departing from the conventional focus on themes in narrative analysis, we embarked on an event-based process analysis (Lok and de Rond, 2013), a post-hoc approach into why certain entrepreneurial opportunities were discovered and taken up at a specific point in time. Eventbased analysis is particularly useful to study path-development because it enabled us to systematically determine the resources and competencies being utilised in each of the economic events and, by comparing events taken by the same entrepreneur, we could work 
out the additional resources and competencies being utilised, and in turn the nature of pathdevelopment being taken. To do so, we followed Langley (1999) and Rosenthal (2006) to first conduct sequential analysis of the biographical data by compiling the collected information into individual case histories for further analysis. This involved firstly constructing a timeline (Tagg, 1985) for the critical life events (Flanagan, 1954; Evers and O'Gorman, 2011; Vorley and Rodgers, 2013) throughout the years, including both preentrepreneurship (P) and entrepreneurship (E) activities, and reflecting on their relationships with related macro and micro incidents. This stage of the analysis enabled us to come up with an objective account of events in their lives, independent from their self-interpretation (Rosenthal, 2006).

In the second stage of the analysis, multiple coding schemes were applied to each case to categorise different events and activities (Rosenthal, 2006; Strauss and Corbin, 1998). This step is particularly essential for biographical research as it enables researchers to separate respondents' self-presented biographical accounts that were developed over the course of their life (Rosenthal, 2006) from our intended research objectives. We first applied an attribute coding scheme (Saldana, 2013) based on Baron (2006) to identify: i) the physical, human and financial resources possessed and acquired by the entrepreneurs to realise the opportunities; ii) their personal knowledge, skills and experiences, both previously accumulated and recently acquired; and iii) their attributes. Once the resources and knowhow had been classified, we determined the nature of path dependence based on Isaksen's (2014) categorisation. Finally, we connected each entrepreneurship event with the self-reported outcomes.

Information gathered was then mapped onto the extended entrepreneurial timelines (Tables 4-6) indicating the nature of each of the entrepreneurship events, the resources and competencies required, and its outcome. We are interested in not only within-case but also 
between-case analyses for generalisation purposes (Ayres et al., 2003). Consistent with LeCompte and Schensul (1999), we examined the correlations between these resources, personal attributes and attitudes, or any combination of them, and certain actions and behavioural outcomes. Finally, as with Merrill and West (2009), we identified common connections between themes across cases for theory generation.

\section{Results and analysis}

\section{Path-continuation at the immediate aftermaths of war and conflict}

The Japanese occupation of Hong Kong in December 1941 meteorically transformed the territory. For the next 3 years and 8 months, ongoing war efforts prohibited trade with outside the 'sphere', effectively bringing all commercial transhipment activities to a halt (Tse, 1995; Cheng, 2006). To ensure that the meagre resources were reserved for military use, the territory was placed under the centralised control of the army, with martial law implemented throughout the occupation (Lethbridge, 1978; Lau and Chow, 2009). Rations on food and fuels were immediately implemented with all private trade and distributions strictly prohibited. Strategically important resources and enterprises were placed under Japanese control, often through confiscation, forced partnership and compulsory takeover under unfavourable terms (Cheng, 2006). The authority imposed an all-night curfew and set up numerous checkpoints across the territory (Snow, 2003). The presence of crime, ongoing warfare and local resistance meant that most civilians would naturally avoid unnecessary travel (Lau and Chow, 2009).

The livelihoods of our three 'would-be' entrepreneurs were closely linked to the business fortune of their respective family businesses. Brother Fok's family fell victim to centralisation as the coal warehouse that they worked for, as well as their carrier, were both confiscated. Brother Fok indefinitely suspended his studies, and for over a year he engaged in 
various types of labour intensive manual work along the waterfront that required little of his pre-existing knowledge and networks (Table 2, \#P-3 to \#P-8). He spoke of his sense of family responsibility which pushed him into jobs that he was not good at, and with little intrinsic or extrinsic reward:

After the confiscation, we had trouble keeping afloat. At 18 and as the only man in the house, I needed a job ... I became a member of a black gang on a steamship...working days and nights, it was tough and tiring. My body was shattered, but I gritted my teeth and pushed on. The wage was low, but at least I could help support the family. However, the boss was not satisfied and let me go... Then I found out that the dockyard was looking for coolies. My job involved hammering nails with a large iron hammer, which was dangerous and exhausting. I could not cope with the physical demands, so I quit... Then I worked as a labourer on the airport extension project. The Japanese would beat me up when I was not deemed to be working hard enough. There was not enough money for proper food, and the lack of nutrition made me weak. I broke my finger because I had no strength to hold onto a barrel... (eventually) I was sacked (Leng, 2010, p15-16).

Sister Li's family kept their two trawlers but clam farming was no longer considered a safe and plausible option. She married a hauler specialising in grocery, but as transportations with major locations such as Macau, Malaysia and the USA came to a halt, demand for their service ceased. Initially she worked for her mother-in-law to trade food stocks obtained from shipwrecks (\#P-C). Smelly rice (fermented in saltwater) was popular, so was soaked wheat or oak that people would turn into porridge. However, stocks were low and soon depleted. She then worked for her sister-in-law collecting leftover food from processing, including tofu residues, peanut skins, and wild vegetables (\#P-D). However, with diminished food stocks, tensions were running high. After her mother-in-law died, she was being accused of causing her death by 'bad feng-shui'. Later, her husband gave her a scoop of rice, and said, 'Take the rice, eat, and move along. We don't have food here.' She became homeless and begged along the harbour front (\#P-E). She was eventually reunited with her mother and returned to lowend haulage (\#E-G), plus any income-generating activities they could land around the harbour. Noticing the locations of the wreckages, the family became metal scrappers and 
small-time copper dealers at the nearby dockyard (\#E-G). These activities were selfsubsistent and not particularly profitable.

With fuel being a strategic resource, the Yip family was able to both keep their fleets and continued to deliver high-end fuels, but now exclusively for the Japanese. Sister Yip effectively continued her path of 'apprenticeship' (\#P-I). Then, with her father's support, she branched out with the purchase of a small carrier to begin her own haulage venture (\#E-II). She recalled:

When my father was busy we transported coals with our residential boat which I ran jointly with my 'small' mother (father's second wife). Sometimes coals were all across the hallway which was hazardous. Then, my father asked me to run my own boat. The first boat was not a good one. My father was still dealing with the suppliers but I had my own coolies and some relatives were working for me. It was largely learning by doing. The flow of business was sporadic and at the beginning I did not make a lot of profit.

This episode illustrates the unpredictability of the environmental jolt which occurs in the immediate aftermaths of war and conflict, where the fortunes of people, businesses and other sectors are often determined by exogenous factors, leaving entrepreneurs with little control over their subsequent success or survival. Winners appear to be arbitrarily chosen, with Sister Yip and her family having the fortune to continue their path as before, a luxury that eluded both the Li and Fok families. There does not appear to be a defined formula explaining why Master Yip's family were allowed to remain in haulage, while Mother Fok's fleets were confiscated. This nevertheless allowed Sister Yip to continue her existing path, and extend it by starting her own venture.

Sister Li and Brother Fok were arguably the losers of the initial jolt. Their paths were repeatedly exhausted, forcing them to switch between self-subsistent local economic activities. Both were pushed into employments out of necessity. Sister Li did eventually manage to begin her entrepreneurship path, but like Sister Yip, this was through extending out from the existing activity that her family were involved in, and was largely by necessity 
rather than choice. Their local involvements provided her with the knowledge and competencies to be sure that a market was available, as well as the means to capture the opportunity. In the midst of change, pursuing new opportunities through the acquisition of new physical capital for far-reaching path-creating or renewal activities would not only be difficult, as access to resources was likely to be limited, but also highly risky, as the conditions could not be predicted.

Brother Fok's education and network beyond the harbour played a minimal role in assisting him during this difficult period. He wanted to move to heartland China which was unaffected by war. However, limited physical mobility was an issue as his mother could not bear the 20-30 days walk to reach the destination. Nevertheless, it is also evident that his bud of entrepreneurship began to grow in the midst of his tragic personal circumstances. He developed a strong conviction in his personal ability but lamented the lack of opportunities and resources for him to start up a business:

I was convinced that I had the brain for business, and could make great wealth... with that in mind, I constantly looked for an opportunity to become rich (Leng, 2010, p20).

For two years since the Japanese occupation, I was involved in six, seven jobs, and every time I was either dismissed or resigned. I began to question whether I was suited to working for other people, and started thinking about starting a business. However, for someone in my circumstances, becoming one's own boss was no easy feat (Leng 2010, p17).

The fact that he no longer resided on boats played a crucial role, as it meant that he did not have the physical resources to speedily capture some of the local transportation and haulage opportunities which had arisen. This resulted in him looking elsewhere when an opportunity subsequently came, as recorded below.

\section{Path-breaking in an increasingly penurious environment}

As with most ongoing warfare or conflicts, the business environment during the rest of the occupation remained treacherously penurious. By 1943, commodity shortages had worsened 
as Japan began to lose ground and, with the American naval blockade in full effect, one merchant ship was sank daily and with it, millions of tons of shipments (Snow, 2003). With most rations being discontinued and the formal economy failing to meet excess demand (Tse, 1995; Cheng, 2006; Snow, 2003), black markets erupted across the territory turning it into 'an anthill of hoarding, speculation and marketeering' (Snow, 2003, 122). Enterprising individuals would source their supplies in a variety of ways: some carried them on foot from across the border (Lau and Chow, 2009), and others like Lady Fok sourced from their own homes items they no longer considered as necessary, such as jewellery, often selling at a deflated price. For obvious reasons of consumption and production, fuel and food commodities were particularly popular. Domestic furniture, papers and books were all considered viable fuels (Lau and Chow, 2009), and many like Sister Li's family gathered firewood from nearby forests. There was even a market for used coal smuggled out by workers from power plants (Snow, 2003). Many of these activities carried substantial dangers with robbery, ongoing bombings and guerrilla battles being commonplace, not to mention the severe punishments if caught. Needless to say, these businesses operated differently from in normal environments, and often required entrepreneurs to be shrewd, streetwise and above all, able to take risks, although some of the risks could be offset by protection payments to police, the triad and others. With few alternative income generation opportunities in a shrinking economy, most engaged in this line of business out of necessity rather than to seek a profit.

The harbour, well-guarded and with relative ease of access in the otherwise paralysed transportation system, was a fitting location for the local black market which ran in parallel to the heavily-controlled formal economy. Such closeness allowed the two economies to interact, in the process legitimising illegitimate commodities and providing the formal sectors with the otherwise unavailable but crucial commodities and support services. This facilitated the growth of entrepreneurship. Sister Yip recalled a busy and vibrant harbour: 
Fisherfolk were running all kinds of business. Some were haulers like us, some sold things, others transported passengers. Most were illegal businesses. As long as you could make money, people would do it.

Sister Yip herself augmented her entrepreneurial path by tapping into the increasingly lucrative illegal fuel trade (\#E-III). She recalled:

In the evenings I would pick up leftover coals from the day's haulage. Many were deliberately kicked into dark corners or cracks. These fuels were in high demand as they were of industrial quality and were deemed superior to used coal and firewood. I also bought coals from other haulers and coolies who sourced them through similar means, but even from children who found them during low-tide. Sometimes when supply was low we paid coal factory workers for their crumbs. We would pack them nicely, and charged customers 2-3 times over.

Whilst 'coal picking' had long been considered as an alternative to tipping, in this new environment the process became systematic and on an industrial scale. Her father, with his network and contacts with factories and ship owners, effectively became the distributor for the family collections.

Initially most of the customers were locals. We would row around to ask, and they would buy when theirs finished. Later, we also sold to strangers who, through repeated dealings, became regulars. We were at our busiest towards the end of the war and had factory, even coal stores' operators. We had those from steam ships coming to us, who would commonly buy 20-30 bags and we would hike the price. At this point I would pass my stock to Dad, who would pay me once he received payment. People looked for my father by shouting his nickname, 'Fatboy-Kei'. The busier it was, the louder the harbour became.

As business began to pick up, she purchased a new boat with his brothers and uncle, a fisherman who helped her father using his trawler. Sister Yip paid for a bigger share but, as the others did more physical work, they split the money equally.

Sister Li continued with haulage and transported goods that were of high demand, in particular fuels such as kerosene and firewood. While doing so, she recognised an increased demand for cross-harbour passenger transportation as public ferries were suspended. Together with her mother, sister and a nephew, they became increasingly involved and reconfigured her trawlers for this specific purpose. Together they purchased a sampan through financial support from an acquaintance in the clam business (\#E-G). She recalled that 
the family "would dock at the pier in the Kowloon side of the harbour, wait for a dozen people, and row them to the Central District, the commercial centre, opposite'. She described the venture as profitable: 'we borrowed \$200, repaid \$20 in each instalment... whilst we charged a dollar a person'. This meant that she could repay her instalments in a matter of two rounds, which could be done in a matter of hours.

Unlike the two sisters, Brother Fok moved away from harbour business and set up a grocery store with finance from relatives and close friends on the harbour front (\#E-9). He served non-perishable food items that were sourced locally from the shipments arriving each day, which he then further processed into a popular food mix. Due to shortages, there was constantly a high demand for these goods and each day there was a long queue of customers waiting outside.

The penurious situation did not improve during the period and, if anything, worsened, but the time they had in the new context allowed entrepreneurial individuals to try to find a path out of all the unpredictability. One of the most notable features of these cases is the reliance on the reconfiguration of resources-at-hand to capture new opportunities. The two sisters augmented the usage of their existing resources and competencies to embark upon path-renewal activities. Nevertheless, the case of Fok illustrates that attaining path-creation with a venture of minimal prior involvement was by no means impossible. Such a move demanded additional resources and competencies beyond what Fok initially possessed, but the path-creation was accomplished through the utilisation of local knowledge and financial supports. While he no longer operated 'in' but 'around' the harbour, the location continued to provide him with knowledge regarding the market demands of the local inhabitants, the knowledge and contacts of the different parts of the supply chain, as well as the finance for the start-ups. 


\section{Constituents of place-dependence at the time of conflict}

A commonality that cut across all the entrepreneurial events occurring during the period of conflict was the importance of place-dependence. All six entrepreneurship events took place around the harbour, and relied on local resources, competencies and networks. Such placedependence is likely to be reinforced by conflict, where physical immobility and the unpredictability of environmental change confines entrepreneurs to their location. The key constructs identified are further discussed below.

\section{Physical resources}

Our cross-case analysis reveals a picture of a mixed usage of pre-existing and acquired physical resources, regardless of the type of path development strategies that these entrepreneurs adopted. Sister Li and Sister Yip both extended into their early ventures (\#E-II, \#E-E and \#E-F) by utilising their dwellings, as well as other equipment, for their existing economic activities. Reconfigurations of these resources were also key to their subsequent path-renewals into the illegal fuel trade (\#E-III) and passenger transportation (\#E-G). The resources allowed the former to operate two businesses concurrently with minimal additional costs, and provided the latter with the flexibility to shift swiftly from one to another when required.

Nevertheless, contrary to expectation, resource acquisitions also played a role. Each of the entrepreneurs, through local finance, purchased a key piece of physical investment for their locally-available path-renewal and creation activities (a store in \#E-9, carriers in \#E-III and \#E-F). Sister Yip relied on family finance:

My father paid the deposit, but I had to pay him back once I started earning... When business was not going well, my father helped me out financially, and I also had to borrow from other relatives. 
Sister Li, in contrast, borrowed money from business acquaintances. Brother Fok adopted a hybrid approach utilising both sources:

With my mother's encouragement and persuasion, dozens of relatives and friends provided me with some money. Combined with my mother's earnings from jewellery pawning, we gathered enough to set up a grocery store...Although this was a joint venture, the majority of the funds were provided by acquaintances, but I was in sole charge of the daily operation (Leng 2010, 20).

\section{Market knowledge}

In each of the events, the possession of local market knowledge regarding supply and demand enabled the entrepreneurs to swiftly identify emerging opportunities much earlier than the outsiders. Being directly involved in the business enabled Sister Yip to realise the room for path-extension as well as for path-renewal into the illegal fuel trade (\#E-III). Once in the harbour, responding to demands for other commodities was not difficult. Sister Yip recalled:

Buyers would yell in the harbour for the products that they wanted, whilst sellers or their acquaintances would shout back in response. There was no difficulty in establishing the demands for different commodities by the frequencies of shouts. We analysed the profiles of the people who responded, including their original lines of business, for any anomalous involvements and their relative status within the harbour.

A non-response would indicate a lack of supply, which could trigger a self-assessment as to whether it would be permissible to tread on the territory of that particular line of products and whether supplies could be sourced via feasible means.

A competitor might have gone away for a day or two or without any supply. We sometimes took on new customers through this route but our competitors would come and argue. My father would deal with that side of things.

Such local market knowledge was crucial to Sister Li's path-renewal (\#E-G), and explains Brother Fok's choice of location for its path-creation (\#E-9).

\section{Local customary knowledge}

The path development of both Sister Yip and Sister Li benefited greatly from the understanding of specific rules regarding the routes, orders, parking spaces, and the other 
'nitty-gritties'. For Sister Yip, knowing the amount of coal she could hold back after each delivery helped her to tread carefully the fine line between tipping and stealing. She recalled:

Some of the bosses (those requesting transportation) would scold us if we took too much. Others would slap my head. I knew some who wouldn't allow anything so I had to be careful. Men could get beaten.

Even in the case of Brother Fok who created a grocery business along the harbour front, his holistic understanding of haulage had given him a crucial supply chain advantage given the general restrictions of land travel and the destruction of transport infrastructures. At the same time, by ensuring that they were tapping into unclaimed territory rather than treading on the paths of other players within the harbour, their activities also obtained legitimacy. Thus whilst harbour life may have appeared unsophisticated to outsiders, Sister Li maintained that the nature of interaction was complex, and required an innate understanding of the harbour, quick wits and intensive strategizing.

\section{Network}

Localised networking appears crucial in all the entrepreneurial events examined. First and foremost, all three entrepreneurs tapped into their local networks for financial support in the acquisition of additional resources for their path-extension, renewal and creation. Alongside trust, the lenders being local enabled them to realistically assess the prospects of these ventures. Secondly, local networks provided a strong support base from which their business could operate. In the case of Sister $\mathrm{Li}$, the involvements of the family in metal scrapping contributed to her decision to devote her meagre physical resources to the effort (\#E-G), just as her family did with clam digging before the war (\#P-B), whilst Sister Yip (\#E-II and \#E-III) drew heavily from her family, in particular her father, for advice, manpower, and technical and backup supports. 
Thirdly, Sister Li and Sister Yip evidently operated as part of a larger cluster alliance, mostly consisting of family members and acquaintances. These alliances offered support in the sharing of physical infrastructures and other valuable resources. For instance, the pooling together of all fuel collected by various family members created economies of scale and had given Master Yip strong bargaining power when negotiating with buyers, which in turn enabled Sister Yip to get a better price for her hauls. The alliance also offered mutual support in times of need. For instance, in handling customers, both Sister Li and Sister Yip had adopted the flexible practice of sharing customers in times of overload, and helped out others when necessary, including providing services and taking orders. These practices provided flexibility and enabled them to embark on other business activities without losing their original customer bases. Finally, local networks provided protection and legitimacy. Both Sister Li and Sister Yip's businesses were legitimised through family engagements. Sister Yip also relied on her father to obtain permission externally from the relevant authorities. She recalled:

My father would pay off the water police on our behalf. When the Japanese boss came to inspect, the police would point them away from our direction and pretend that they did not see us with our goods. Afterwards they would come to collect the money. Of course there was no guarantee. If their boss decided to inspect us then they could do nothing - we had no means (network, language) to bribe them.

\section{Discussion and conclusion}

We believe that our study of the conflict situations offers important contributions to further our understanding of the role of temporal and spatial contexts in the processes of entrepreneurial opportunity recognition and venture development. Our expectation of a 'double whammy' effect of penurious environment and conflict situation on confining the path development of entrepreneurial ventures is only partially correct. Consistent with Brekke (2015) and Isaksen (2015), in the immediate aftermaths of conflict, the triple helix of chaos, unpredictable destruction of factor endowments and physical immobility does make the 
penurious environment even more resource-poor, diminishing the capabilities to engage in non-necessity-based economic activities and confining entrepreneurial individuals to pathcontinuation. Factors that were traditionally considered entrepreneurship enablers, such as education (Thompson et al., 2010, 2009), offer minimal additional advantage. However, contrary to our expectations, as entrepreneurial individuals immersed themselves into the new order, they recognised new entrepreneurial opportunities through renewing and creating new paths by efficiently reconfiguring the meagre resources towards new purposes. Paucity, which one would expect to deter entrepreneurship activities, unexpectedly becomes the necessity push towards path-breaking entrepreneurial endeavours. Therefore, alongside transplantation which has been identified in Isaksen (2014) and Brekke (2014) as a crucial enabler in a penurious environment, our findings identify necessity push as an alternative, equivalent mechanism in the context of conflict. Our finding is also broadly consistent with the 'effectuation' proposition in relation to entrepreneurial decisions in uncertain environments (Sarasvathy, 2001), Baron's (2006) 'entrepreneurial actions', or Ucbasaran et al.'s (2011) 'organisational learning', all of which suggest that it is down to the entrepreneurial individuals to cognitively dissect the external context and internal competencies in coming up with heterogeneous entrepreneurial paths.

Our study highlights the importance of place at a time of conflict, consistent with Cohen and Levinthal (1990). Firstly, physical immobility enabled the incumbents who were confined to the location to monopolise economic activities and explains the lack of competition from outsiders (Zahra et al., 2014). There can be an element of luck, but other locations may also be able to develop specific spatial advantages that can be uniquely captured by individuals confined to them (Boschma, 2005; Brekke, 2014). Secondly, the rapidly-changing context resulted in the need to swiftly capture and exploit opportunities before they became obsolete (Short et al., 2010). Pressure of time had, as the literature 
suggested (Cunha, et al., 2014), pushed entrepreneurial individuals towards a localised approach of improvisation in order to simultaneously plan and execute. Thirdly, environmental changes, as Cohen and Winn (2008) suggested, create voids that only those within the particular locale can spot, facilitating not only path-continuation, but also pathbreaking, even in regressive shake-ups induced by conflict. Whilst the voids created by conflict may not be immediately obvious due to high uncertainties, we found that earlymovers are likely to be those with a superior local resource base.

Our cases support the place-dependence hypothesis. In all cases, local knowledge, as Audretsch and Keilback (2007) suggested, plays an important role in opportunity recognition, while local resources offer an effective and quick fix for the resource mobilisation problems faced by entrepreneurs in a penurious environment. Consistent with the literature (Pfeffer and Salancik, 2003; Emerson, 1962), we found the local network crucial in tackling hoarding to acquire resources. These explain why place-dependence is even more prominent in the conflict environment and, despite increasing resource constraints, path-exhaustion appears only temporary, with entrepreneurs remaining active in pursuing opportunities that not only extend their existing entrepreneurship path, but also renew and create new ones.

The main managerial implication is that entrepreneurs need not be disheartened by the confining context, even when it may have led them towards path-exhaustion. Local knowledge can serve as a strong weapon in tackling the penurious conflict environment and provide them with a clear competitive advantage that cannot be replicated by outsiders. Our study is not recommending entrepreneurs to remain where they are during conflict, as we did not compare how the ventures of those who stayed, and those who left, fared. Our particular case merely demonstrates the difficulty of branching out from the harbour with a base in the harbour. Social enterprises or relief organisations supporting those affected by conflict could consider enabling bottom-up, local self-help forms of support, with the aim of facilitating 
local knowledge, resource and network dissemination in aid of business start-ups. This would enable them to survive through such difficult periods.

We also wish to use the conclusion to argue that entrepreneurial development is beyond a matter of survival. It is also about channelling energy to do something that people are passionate about, and something worthwhile. One issue that, due to coverage limitations, this paper is unable to highlight, is the empowerment effect of entrepreneurship at the time of conflict. All three subjects spoke vividly of their war time businesses. Brother Fok clearly remembers all the details of his daily routine, including the kind of food mix that he had to prepare, and how he neglected his recently-wedded wife and spent days and nights in the grocery store. He mentioned many times living a life without regret, and not having to rely on others. Despite constantly complaining throughout the interviews of the toughness of running a business, Sister Yip spoke of it as a significant event in her coming of age. With a grin on her face, she recalled:

With my own boat, my dad gave me my share of earning rather than pocket money. Splitting money was the happiest moment for all. With the hard earned money I loved to buy food and share it with others. It felt great. I also paid some money back to my big mother. I felt independent - like an adult (she was about 16-17).

For Sister $\mathrm{Li}$, as a pensioner reflecting on her entrepreneurial journey, the main emotions that came out of the interviews were fondness and pride. All these suggest the powerful role entrepreneurship can play in a time of conflict beyond self-subsistence, creating positive energy and resilience, which is crucial to surviving such tough and depressing times (Bullough et al., 2015).

Finally, we would like to discuss the limitations of the study and recommendations for further research. Firstly, a quantitative study involving an enriched sample size would enable a confirmatory approach in examining the relationship between path-development, resource utilisation strategies, and performance outcomes. Secondly, different types of conflict may 
result in different forms of path-development which can be further studied. Finally, studies could examine the transformation in the subsequent era of peace. The fortunes of the three entrepreneurs could not be more different. Brother Fok continued to create new paths and eventually became a millionaire. When the penurious nature of the harbour became a hindrance as normality was restored, he invested away from the harbour and is no longer place-dependent. Brother Fok's education and networks beyond the harbour, as well as an entrepreneurial outlook, enabled him to do so. Sister Yip and Sister Li continued to be placedependent, as both returned to their old paths in haulage. Such a path was eventually exhausted, for the former immediately after the war, and for the latter after three decades. This shows that the imaginative variant does triumph; however, further analysis of their postwar path development is beyond the remit of this paper and therefore further study towards this would be welcomed. 
Table 1. Summary of the different means of path-dependence

\begin{tabular}{|c|c|c|c|c|}
\hline $\begin{array}{l}\text { Path } \\
\text { development }\end{array}$ & Nature & Main characteristics & Method & Outcome \\
\hline $\begin{array}{l}\text { Path- } \\
\text { extension }\end{array}$ & $\begin{array}{l}\text { Path } \\
\text { continuation }\end{array}$ & $\begin{array}{l}\text { A situation whereby entrepreneurs } \\
\text { take the intentional decision to } \\
\text { continue along the existing trajectory. }\end{array}$ & $\begin{array}{l}\text { Embark upon the 'doing, using and } \\
\text { interacting' (DUI) model of innovation } \\
\text { (Isaksen, 2014). }\end{array}$ & $\begin{array}{l}\text { Incremental development of } \\
\text { products and services based } \\
\text { on the existing offerings } \\
\text { (Jensen et al., 2007). }\end{array}$ \\
\hline $\begin{array}{l}\text { Path- } \\
\text { exhaustion }\end{array}$ & & $\begin{array}{l}\text { Entrepreneurs continue along the } \\
\text { existing trajectory, but the situation } \\
\text { no longer favours the activity that the } \\
\text { entrepreneur has chosen to embark } \\
\text { upon. }\end{array}$ & $\begin{array}{l}\text { Historical over-reliance on specific } \\
\text { skillsets and resources that for purpose } \\
\text { become obsolete (Grabher, 1993). }\end{array}$ & $\begin{array}{l}\text { Negative locked-in situation } \\
\text { and unable to resurrect the } \\
\text { downturn (Brekke, 2014). }\end{array}$ \\
\hline Path-renewal & $\begin{array}{l}\text { Path- } \\
\text { breaking: } \\
\text { Require } \\
\text { strategic } \\
\text { change }\end{array}$ & $\begin{array}{l}\text { A situation when entrepreneurs } \\
\text { branch out into new business sectors } \\
\text { based on pre-existing competencies } \\
\text { and resources. }\end{array}$ & $\begin{array}{l}\text { Partly through resource reconfiguration } \\
\text { supplemented by new knowledge and } \\
\text { competencies acquisition (Baker and } \\
\text { Nelson, 2005). }\end{array}$ & $\begin{array}{l}\text { Enter new sector that is } \\
\text { technologically related which } \\
\text { enables smooth transition } \\
\text { (Neffke and Henning, 2011). }\end{array}$ \\
\hline Path-creation & & $\begin{array}{l}\text { A situation when entrepreneurs } \\
\text { mindfully venture away from their } \\
\text { existing competencies and resources } \\
\text { and embark on activities in relatively } \\
\text { unknown sectors. }\end{array}$ & $\begin{array}{l}\text { Requires access to new knowledge, } \\
\text { competencies and skills that is usually } \\
\text { obtained through external resource } \\
\text { acquisition (Garud and Karone, 2001; } \\
\text { Martin and Sunley, 2010). }\end{array}$ & $\begin{array}{l}\text { Enter new sector that is } \\
\text { technologically unrelated, } \\
\text { causing dramatic changes } \\
\text { (Isaksen, 2014). }\end{array}$ \\
\hline
\end{tabular}


Table 2. Family Profile and Pre-entrepreneurship Experiences of our Three Entrepreneurs

\begin{tabular}{|c|c|c|c|}
\hline & Sister Yip & Sister Li & Brother Fok \\
\hline $\begin{array}{l}\text { Summary } \\
\text { of family } \\
\text { history }\end{array}$ & $\begin{array}{l}\text { Eldest daughter of a family that } \\
\text { specialised in the delivery of coal, } \\
\text { charcoal and high quality Singaporean } \\
\text { firewood for industrial uses on a large } \\
\text { scale, considered to be a good line of } \\
\text { business as supply and demand for these } \\
\text { goods were relatively stable. } \\
\text { Father (Master Yip) at the time was a } \\
\text { senior figure in the trade. }\end{array}$ & $\begin{array}{l}\text { In the trade for four generations with relatives scattered } \\
\text { across the harbour. } \\
\text { Initially operated a sizeable wooden carrier handling mostly } \\
\text { dried food products; when Japanese invasion of Southern } \\
\text { China began, food supplies became erratic. } \\
\text { Failed to keep up with ship maintenance and left the } \\
\text { business with large debts, the carrier eventually became un- } \\
\text { sailable. Father suffered from depression. } \\
\text { Acquired enough resources for two small trawlers for } \\
\text { offshore fishing, but was unsuccessful due to lack of skills } \\
\text { and knowhow. } \\
\text { Moved onto inshore clamming with support from extended } \\
\text { family. }\end{array}$ & $\begin{array}{l}\text { - Brought up in a 'fisher folk' family in the haulage } \\
\text { profession. Grandfather owned an intercity } \\
\text { steamer. } \\
\text { - } \text { Lost his father to cancer and two elder brothers } \\
\text { to typhoon when he was seven. } \\
\text { - Forced to abandon the family boat in search for } \\
\text { opportunities ashore. Moved into a nearby } \\
\text { ghetto in a } 20 \mathrm{~m}^{2} \text { room with } 50 \text { other people. } \\
\text { Mother (Lady Fok) bought sewing machine to } \\
\text { start dress making and repair assisted by } \\
\text { Brother Fok, but lacked understanding of local } \\
\text { dress codes. } \\
\text { Returned to the harbour, and through her } \\
\text { connections, obtained a contract with a fairly } \\
\text { large Chinese coal trader. }\end{array}$ \\
\hline $\begin{array}{l}\text { Family } \\
\text { possession } \\
\mathrm{s} \text { at the } \\
\text { time of } \\
\text { the } \\
\text { conflict }\end{array}$ & $\begin{array}{l}\text { - Wooden trading coaster and a number of } \\
\text { sampans } \\
\text { - Residential boat. }\end{array}$ & - Two small trawlers & $\begin{array}{l}\text { - Co-owned a small steamer with associates } \\
\text { - A property along the seafront both as their } \\
\text { residence as well as a common room for coolies } \\
\text { on standby. }\end{array}$ \\
\hline Education & No education, illiterate & $\begin{array}{l}\text { Taught basic Chinese characters by her father and attended a } \\
\text { missionary school for six months. }\end{array}$ & $\begin{array}{l}\text { Admitted to one of the most prestigious secondary } \\
\text { schools in the colony, and remained there until the } \\
\text { Japanese invasion at which point he was preparing } \\
\text { for his university entrance exam. }\end{array}$ \\
\hline $\begin{array}{l}\text { Role } \\
\text { within the } \\
\text { haulage } \\
\text { business }\end{array}$ & $\begin{array}{l}\text { Provided backroom support to the operation, } \\
\text { including the cleaning of the equipment as } \\
\text { well as light physical work. }\end{array}$ & $\begin{array}{l}\text { Literacy enabled her to handle goods exchange and other } \\
\text { supervisory roles. }\end{array}$ & $\begin{array}{l}\text { Helped out with the family business whenever he } \\
\text { could and had acquired considerable experience in } \\
\text { the haulage business. }\end{array}$ \\
\hline
\end{tabular}




\begin{tabular}{|c|c|c|c|}
\hline $\begin{array}{l}\text { Pre- } \\
\text { entrepren } \\
\text { eurship } \\
\text { work } \\
\text { experienc } \\
\text { es }\end{array}$ & $\begin{array}{l}\text { Before war and during conflict: haulage } \\
\text { apprenticeship within family (\#P-I). }\end{array}$ & $\begin{array}{l}\text { Before war: haulage apprenticeship within family (\#P-A), } \\
\text { clamming business with family (\#P-B), grocery apprenticeship } \\
\text { within family (\#P-C), selling leftover food from food processing } \\
\text { (\#P-D) } \\
\text { During conflict: beggar (\#P-E) }\end{array}$ & $\begin{array}{l}\text { Before war: haulage apprenticeship within family } \\
\text { (\#P-3) } \\
\text { During conflict: black gang in the engine room of the } \\
\text { steam ship (\#P-4), coolie in a dockyard (\#P-5), } \\
\text { worker at the airport (\#P-6), dockyard (\#P-7), } \\
\text { refinery (\#P-8) and granary (\#P-9). }\end{array}$ \\
\hline
\end{tabular}


Table 3. Comparison of the Interviews taken in the three cases

\begin{tabular}{|c|c|c|c|}
\hline & Sister Yip & Sister Li & Brother Fok \\
\hline $\begin{array}{l}\text { Main } \\
\text { source }\end{array}$ & $\begin{array}{l}\text { Interviews conducted by a local researcher utilising } \\
\text { methodology consistent with the Hong Kong Oral History } \\
\text { Archive Project. This includes full (unedited) narratives } \\
\text { and audio tapes. A summarised and edited version was } \\
\text { subsequently published as Cheung, } 2015 \text {. }\end{array}$ & $\begin{array}{l}\text { Interviews conducted by a local historian over a number } \\
\text { of meetings as part of the Hong Kong Oral History Archive } \\
\text { Project, with both the original (unedited) audio tapes and } \\
\text { transcripts being published as Li (2012). }\end{array}$ & $\begin{array}{l}\text { The Brother Fok's case is based on a selection of } \\
\text { narratives from interviews that were conducted } \\
\text { by a local journalist, also his official biographer, } \\
\text { and was subsequently published as Leng (2010) } 10 \\
\text { years after the biography was published. Only } \\
\text { selected narratives included. Extensive } \\
\text { grammatical editing with less well presented } \\
\text { repeated materials erased. Some pauses edited } \\
\text { out, whilst others were kept. }\end{array}$ \\
\hline Structure & Open-ended, unstructured & Open-ended, unstructured & Open-ended, unstructured \\
\hline $\begin{array}{l}\text { Major } \\
\text { themes } \\
\text { Covered }\end{array}$ & $\begin{array}{l}\text { Business Experience, Life on the water, Childhood, War, } \\
\text { Family/ marriage, Personal context embedded in a larger } \\
\text { temporal, social context. Some elaborations on second- } \\
\text { hand information, such as rumour or hearsay, but the } \\
\text { interviewers would ask the interviewees to clarify how } \\
\text { these events were connected to their lives. }\end{array}$ & $\begin{array}{l}\text { Business Experience, Life on the water, Childhood, War, } \\
\text { Family/ marriage, Hobbies, Discrimination, Personal } \\
\text { context embedded in a larger temporal, social context. } \\
\text { Some elaborations on second-hand information, such as } \\
\text { rumour or hearsay, but the interviewers would ask the } \\
\text { interviewees to clarify how these events were connected } \\
\text { to their lives. }\end{array}$ & $\begin{array}{l}\text { Business Experience, Life on the water, Childhood, } \\
\text { War, Family/ marriage, Sports, Political } \\
\text { Involvements, Personal context embedded in a } \\
\text { larger temporal, social context. Some elaborations } \\
\text { on second-hand information, such as rumour or } \\
\text { hearsay. }\end{array}$ \\
\hline
\end{tabular}




\begin{tabular}{|c|c|c|c|}
\hline $\begin{array}{l}\text { Repeated } \\
\text { interviews }\end{array}$ & Yes & Yes & Yes \\
\hline $\begin{array}{l}\text { Other } \\
\text { sources }\end{array}$ & Narratives from family members & None & $\begin{array}{l}\text { Other official biography, narratives from family } \\
\text { members, unofficial biographies, company } \\
\text { records, news archives. }\end{array}$ \\
\hline
\end{tabular}


Table 4. Timeline for Sister Yip's entrepreneurial venture

\begin{tabular}{|c|c|c|c|c|c|c|}
\hline $\begin{array}{l}\text { Event } \\
\text { and } \\
\text { Year }\end{array}$ & $\begin{array}{l}\text { Nature of } \\
\text { opportunity and how } \\
\text { it became noticed. }\end{array}$ & $\begin{array}{l}\text { Resource } \\
\text { strategy } \\
\text { and action }\end{array}$ & Distance & Enablers/ resource at hand & $\begin{array}{l}\text { Major resource and skills } \\
\text { reconfiguration and acquisition }\end{array}$ & Reported Outcomes \\
\hline $\begin{array}{l}E-I I \\
1942\end{array}$ & $\begin{array}{l}\text { Coal transportation. } \\
\text { She was already in } \\
\text { the business. }\end{array}$ & $\begin{array}{l}\text { Path } \\
\text { expansion }\end{array}$ & $\begin{array}{l}\text { Sectoral: Same sector, same } \\
\text { industry } \\
\text { Product: Same product } \\
\text { Physical: Same market location }\end{array}$ & $\begin{array}{l}\text { Environmental: Family was } \\
\text { allowed by the authority to } \\
\text { continue the business. } \\
\text { Financial: Financial backing } \\
\text { from her family } \\
\text { Capacity: Pre-existing } \\
\text { knowledge and experiences in } \\
\text { haulage of fuel accumulated } \\
\text { through working for her father. }\end{array}$ & $\begin{array}{l}\text { Acquisition: Purchased a wooden } \\
\text { carrier through family finance. } \\
\text { Reconfiguration: No } \\
\text { reconfiguration required. She } \\
\text { transferred basic equipment from } \\
\text { the existing family business. }\end{array}$ & $\begin{array}{l}\text { Successful: made steady } \\
\text { profit during the War. } \\
\text { However, intense } \\
\text { competition after the War } \\
\text { reduced the profits, and } \\
\text { began to look elsewhere. }\end{array}$ \\
\hline $\begin{array}{l}\text { E-III } \\
\text { Same } \\
\text { year } \\
\text { as } \\
\text { above }\end{array}$ & $\begin{array}{l}\text { Illegal fuel trade - } \\
\text { systematic extraction } \\
\text { of fuel through 'coal } \\
\text { picking'. She noticed } \\
\text { large demand while } \\
\text { conducting haulage } \\
\text { and that many } \\
\text { people enquired } \\
\text { after fuels. Family } \\
\text { discussed and } \\
\text { identified it as a } \\
\text { profit maker. }\end{array}$ & $\begin{array}{l}\text { Path } \\
\text { renewal }\end{array}$ & $\begin{array}{l}\text { Sectoral: different sector (from } \\
\text { haulage to trading) } \\
\text { Product: same product } \\
\text { Physical: Same location }\end{array}$ & $\begin{array}{l}\text { Environmental: Fuel shortage } \\
\text { during the War created the } \\
\text { demand for fuel. } \\
\text { Financial: Low additional cost } \\
\text { from the haulage business that } \\
\text { received family backing. } \\
\text { Capacity: Pre-existing } \\
\text { knowledge and experiences in } \\
\text { haulage of fuel. } \\
\text { Family connections to identify } \\
\text { potential buyers and } \\
\text { acknowledgement from the } \\
\text { authority. }\end{array}$ & $\begin{array}{l}\text { Acquisition: None required } \\
\text { Reconfiguration: Small change in } \\
\text { routine. Liaised with coolies and } \\
\text { other parties for suppliers. }\end{array}$ & $\begin{array}{l}\text { Successful: highly } \\
\text { profitable during the War. } \\
\text { The business ended } \\
\text { immediately after the } \\
\text { WW2 when fuel supply } \\
\text { returned to normal. }\end{array}$ \\
\hline
\end{tabular}


Table 5. Timeline for Sister Li's entrepreneurial venture

\begin{tabular}{|c|c|c|c|c|c|c|}
\hline $\begin{array}{l}\text { Event } \\
\text { and } \\
\text { Year }\end{array}$ & $\begin{array}{l}\text { Nature of opportunity and } \\
\text { how it became noticed }\end{array}$ & $\begin{array}{l}\text { Resource } \\
\text { strategy } \\
\text { and action }\end{array}$ & Distance & Enablers/ resource at hand & $\begin{array}{l}\text { Major resource and skills } \\
\text { reconfiguration and acquisition }\end{array}$ & $\begin{array}{l}\text { Reported } \\
\text { Outcomes }\end{array}$ \\
\hline $\begin{array}{l}\text { E-E } \\
1942-3\end{array}$ & $\begin{array}{l}\text { Low-end haulage - forced to } \\
\text { return to previous } \\
\text { competencies as source of } \\
\text { clams depleted. High demand } \\
\text { for fuel transportation. }\end{array}$ & $\begin{array}{l}\text { Path } \\
\text { extension }\end{array}$ & $\begin{array}{l}\text { Sectoral: Same sector/ } \\
\text { industry from the ones the } \\
\text { family engaged in. } \\
\text { Product: Same product } \\
\frac{\text { Physical: Another part of the }}{\text { harbour. }}\end{array}$ & $\begin{array}{l}\text { Environmental: High demand for fuel } \\
\text { transportation. } \\
\text { Financial: Minimal financial } \\
\text { requirements } \\
\text { Capacity: } 2 \text { trawlers, and innate } \\
\text { understanding of the activities around } \\
\text { the harbour }\end{array}$ & $\begin{array}{l}\text { Acquisition: None made } \\
\text { Reconfiguration: Changed use of } \\
\text { trawlers for the transportation of } \\
\text { fuel and other ad-hoc haulage } \\
\text { activities. }\end{array}$ & Self-subsistence \\
\hline $\begin{array}{l}\text { E-F } \\
1942-3\end{array}$ & $\begin{array}{l}\text { Metal scrapping - Brief } \\
\text { experience as scrapper of } \\
\text { products and materials from } \\
\text { boats and battleships that } \\
\text { were sunk during the War } \\
\text { made them aware of the } \\
\text { opportunity. She was aware } \\
\text { of the locations of dockyards } \\
\text { and buyers. }\end{array}$ & $\begin{array}{l}\text { Path } \\
\text { extension }\end{array}$ & $\begin{array}{l}\text { Sectoral: Same sector/ } \\
\text { industry from the ones the } \\
\text { family engaged in. } \\
\text { Product: Same product } \\
\frac{\text { Physical: Another part of the }}{\text { harbour. }}\end{array}$ & $\begin{array}{l}\text { Environmental: High demand for metal } \\
\text { and good supply due to destruction of } \\
\text { boats and battleships. } \\
\text { Financial: Minimal financial } \\
\text { requirements } \\
\text { Capacity: } 2 \text { trawlers allowed access to } \\
\text { dockyards and buyers, pre-existing } \\
\text { experience as scrapper of products } \\
\text { and materials from boats and } \\
\text { battleships that were sunk during the } \\
\text { War, and innate understanding of the } \\
\text { activities around the harbour. }\end{array}$ & $\begin{array}{l}\text { Acquisition: None made } \\
\text { Reconfiguration: Changed use of } \\
\text { trawlers for the transportation of } \\
\text { metals, and to follow new } \\
\text { industry norm. }\end{array}$ & Self-subsistence \\
\hline $\begin{array}{l}\text { E-G } \\
1944\end{array}$ & $\begin{array}{l}\text { Cross-harbour passenger } \\
\text { transportation - She was } \\
\text { aware of the lack of transport } \\
\text { across harbour. }\end{array}$ & $\begin{array}{l}\text { Path } \\
\text { renewal }\end{array}$ & $\begin{array}{l}\text { Sectoral: Different sector } \\
\text { Market: Different customer } \\
\text { clientele }\end{array}$ & $\begin{array}{l}\text { Financial: Financial backing from } \\
\text { relatives. Borrowed Y200 from } \\
\text { relatives but was able to charged Y1 } \\
\text { per passenger and had no problem }\end{array}$ & $\begin{array}{l}\text { Acquisition: Purchased a } \\
\text { passenger sampan through loan } \\
\text { from relatives. } \\
\text { Reconfiguration: Change used of }\end{array}$ & $\begin{array}{l}\text { Successful: } \\
\text { Profitable, but } \\
\text { venture expired } \\
\text { as cross-harbour }\end{array}$ \\
\hline
\end{tabular}




\begin{tabular}{|l|l|l|l|l|l|}
\hline & & $\begin{array}{l}\text { Physical: Another part of the } \\
\text { harbour. }\end{array}$ & $\begin{array}{l}\text { repaying the loan by instalments. } \\
\text { Capacity: Ability to navigate around } \\
\text { the harbour. }\end{array}$ & $\begin{array}{l}\text { trawler to passenger } \\
\text { transportation, placed emphasis } \\
\text { on customer-facing skills, and } \\
\text { followed new sector norm. }\end{array}$ & $\begin{array}{l}\text { passenger } \\
\text { transport } \\
\text { returned to } \\
\text { normal. }\end{array}$ \\
\hline
\end{tabular}


Table 6. Timeline for Brother Fok's employment experiences and his entrepreneurial venture

\begin{tabular}{|c|c|c|c|c|c|c|}
\hline Year & $\begin{array}{l}\text { Nature of } \\
\text { opportunity and } \\
\text { how it became } \\
\text { noticed. }\end{array}$ & $\begin{array}{l}\text { Resource } \\
\text { strategy } \\
\text { and action }\end{array}$ & Distance & Enablers/ resource at hand & $\begin{array}{l}\text { Major resource and skills } \\
\text { reconfiguration and acquisition }\end{array}$ & Reported Outcomes \\
\hline $\begin{array}{l}1943 \\
E-9\end{array}$ & $\begin{array}{l}\text { Opened a grocery } \\
\text { store as he noticed } \\
\text { a high demand for } \\
\text { food products } \\
\text { around the } \\
\text { harbour. }\end{array}$ & $\begin{array}{l}\text { Path } \\
\text { creation }\end{array}$ & $\begin{array}{l}\text { Sectoral: New sector } \\
\text { vaguely connected to } \\
\text { previous family } \\
\text { haulage business. } \\
\text { Physical: The harbour } \\
\text { front } \\
\text { Product: Unfamiliar } \\
\text { product }\end{array}$ & $\begin{array}{l}\text { Environmental: War and conflict led } \\
\text { to high demand for food products. } \\
\text { Financial: Borrowed from } \\
\text { acquaintances. } \\
\text { Capacity: Understanding of the local } \\
\text { demand for food products. } \\
\text { Understanding of the local suppliers. }\end{array}$ & $\begin{array}{l}\text { Acquisition: New shop through finance } \\
\text { from acquaintances. } \\
\text { Reconfiguration: Major reconfiguration } \\
\text { required: new products, routines, } \\
\text { industry rules, and more emphasis on } \\
\text { customer facing skills. }\end{array}$ & $\begin{array}{l}\text { Successful: it was profitable } \\
\text { but closed after WW2 to } \\
\text { return to haulage. }\end{array}$ \\
\hline
\end{tabular}

